\title{
Urban Consumption and Feelings of Attachment of Rotterdam's New Middle Class
}

\author{
by Marco van der Land \\ OTB Research Institute for Housing, Urban and Mobility Studies, Delft Technical University, The \\ Netherlands
}

Sociological Research Online, Volume 10, Issue 2,

$<$ http://umw. socresonline.org.uk/10/2/vanderland.html>

doi:10.5153/sro. 1098

Received: 13 Oct 2004 Accepted: 20 Jun 2005 Published: 30 Jun 2005

\begin{abstract}
Cities have increasingly developed into spaces for consumption. This paper explores the relationship between patterns of use of urban leisure amenities and feelings of attachment to the city. A survey among highly educated professionals and managers (the new middle class, working in the Dutch city of Rotterdam) was carried out in order to examine both their participation in the domain of urban leisure and urban residence, and their attachments to the city in general. The survey shows that among the new middle class subgroupings can be identified, based on their mobility with regard to leisure and their psychological attachments to the city. One of them is a group of young single urban households, who are not only frequent urban consumers, but who also feel strongly attached to the city as a whole. The findings suggest that in cities specific processes of symbolic consumption occur which facilitate some extent of psychological attachment and which appear to tie a subset of the new middle class to urban places, regardless of place of residence.
\end{abstract}

\section{Keywords: New Middle Class, Symbolic Consumption, Urban Sociology}

\section{Introduction}

The city is mine. I am from here. Each time I go here or there, and I see this or that, it moves me. (Wentholt 1968: 77). [transl. MvdL]

1.1 During the twentieth century cities have developed into places for consumption par excellence (Hannigan 1998, Zukin 1998). People buy, stroll and play in cities, they watch and are looked at, they entertain and are being entertained (Lofland 1989). The city, moreover, is a special place for consumption. Not only is the city a kind of container for all kinds of consumption goods and services, it is also a consumption phenomenon on its own. Consumption in the city is a highly symbolic and social phenomenon. First, the urban environment and the diversity of activities which take place there, allow for the non-monetary consumption of urban experiences (like streetshows, skateramps, the urban hustle, the historic ambiance). Second, it is also a centre for art exhibitions, concerts and buying exclusive goods. People take in images and impressions in the presence of, and interaction with, others.

1.2 For some time now, the city as a domain of consumption has been subjected to much critical debate. As a result of the commercialization of all kinds of consumption activities, some authors claim that the city is increasingly void of 'authentic meaning' (Mommaas 2002). Others claim that urban centres are increasingly 'regulated spaces' in which spontaneous ideas and cultural initiatives are more and more repressed (Zukin 1991, Gottdiener 1997). Emotional bonds and very personal relationships with a place develop over time and through repeated interactions, especially by maintaining social relations with others there (Low \& Altman 1992). The development of cities into consumption domains urges the question of whether the city is still a place people feel psychologically attached to, especially as selective migration over decades has led to a decline in urban ties developing through actually living in the Netherlands.

1.3 In this paper the possible relationship between symbolic consumption and the development of feelings of attachment to the city will be explored, through culture, spectacle and residence. This is done by focussing on the so-called 'new middle class' of Rotterdam, a category of people who are the main target group of $\mathrm{dS}+\mathrm{V}$, the council's Department of Urban Planning and Housing. In most of the larger Dutch cities, the new middle class largely lives outside the city, either in the countryside or in small towns near the city 
(van der Wouden \& de Bruijne 2001). Rotterdam is a prime example of this and has resulted in the administration trying to keep new middle class households from moving away. Not only is this new middle class still considered to be representing bourgeois values like solidarity and a sense of public responsibility, they are considered to be essential for sustaining a transformation into a full fledged postindustrial economy in two ways. First, due to their high levels of economic and cultural capital, the new middle class are thought to be bearers and drivers of the consumption and culture driven economic sectors. It is suggested they display an urban consumption oriented lifestyle, both regarding the art and culture complex, as well as inner city shopping, entertainment and catering (Featherstone 1990, Shields 1992, O'Connor \& Wynne 1995). Second, the presence of a new middle class is an important condition and pull factor for knowledge intensive and creative industries (Scott, 1988, Florida 2002).

1.4 The argument in this paper develops along the following lines. After discussing the new middle class and the city of Rotterdam, I analyse the popularity of the leisure facilities among the new middle class living in Rotterdam and conclude that a high proportion is not very mobile with regard to leisure. The analysis then moves on to those living in the centre of Rotterdam and shows that the development of the city into a leisure city does not for some (yet) seem to be at odds with the residential function. Young and single highly qualified workers from the producer services make up the predominant new middle class section living in Rotterdam's centre and they are also frequent users of its leisure facilities. Next, attention shifts to the psychological attachment of the new middle class to the city. The degrees of attachment frequent leisure consumers, both living inside and outside the city, suggest they have to the city leads us to hypothesize that the presence of leisure facilities in cities has a psychological (cognitive and emotional) dimension, which is related to the presence of others and which stimulates rather than discourages the development of psychological attachments to the city.

\section{Urban leisure, housing and the new middle class}

2.1 In the debate on urban culture and consumption the new middle class takes centre stage (Wynne 2002). Some perceive their role as having been decisive for the postindustrialisation of contemporary cities and the development of consumer culture. The symbol-intensive character of new middle class occupations would not only have turned them into the driving force behind the urban transformation from a production centre into a consumption centre, but, due to their positions in production and consumption relations, the new middle class is also the main beneficiary of this transformation. Both the production and reproduction of images and meanings which have pervaded the city, can be traced back to their claimed 'postmodern predisposition' towards a postmodern culture in which high and popular culture are mingled (Lash \& Urry 1987, Featherstone 1990, Bourdieu 1992).

2.2 As a result of this postmodern predisposition, the new middle class is thought of as a typically urban social stratum, both in academic literature (see e.g. Featherstone 1990, Sassen 1991) and popular literature (see e.g. novels by Tom Wolfe or David Lodge). In Bourdieuan terms, the cultural participation of the new middle class, their ownership of cultural goods, spending power and their particular lifestyles all are means of distinction, which can be exposed well in the context of the city. The need for distinction as well as demographic, economic and cultural changes are believed to shape the demand for urban dwellings by the new middle class (Ley 1996). For example, economic structural factors, the most important being the rent-gap of urban dwellings in or near the centre of cities, is one element shaping the gentrification of dilapidated urban neighbourhoods (Smith 1996). Whilst partly the result of changing gender roles, but also efficient time-use, many such urban new middle class households look for an environment offering high quality urban consumption experiences as close to home as possible (Knulst 1992, Van der Land 1998).

2.3 For members of the urban new middle class, urban symbolic consumption can thus become a habitual element of life, familiarizing them with local places, people, customs and special characteristics (SchmidtRelenberg 1968). Consumption is both about products and about people, and therefore very much a social and cultural activity. Social contacts in the domain of urban consumption can be intense but temporary, and highly expressive but partial and flexible (Bauman 1990, Shields 1992). With regard to the cultural dimension of symbolic consumption, the exchange of symbols, what is consumed, and even more important, how it is consumed conveys messages about identity. Elements of symbolic consumption can include "personal ornaments, modes of social display, aestheticised objects, forms of entertainment and distraction, or sources of information and self-awareness" (Scott 1997:323/4). In the urban public realm it is not necessary to know each other by name to have a feeling of togetherness (Maffesoli 1996). Spaces of consumption are experiential spaces (Lash \& Urry 1987, Schulze 1992), where related structures of feeling can be found. People can in a way extract a feeling of togetherness from the presence of others even when these others differ completely from what one is accustomed to (Hajer \& Reijndorp 2002). Such cultural differences form an essential part of identity construction and symbolic consumption (Campbell 1987, Bourdieu 1992).

\section{Rotterdam}


3.1 The Rotterdam housing stock has traditionally been strongly aimed at the working class. Urban renewal, during the 1970s and 1980s, in Rotterdam, (which is the second largest city of the Netherlands with a population of 599.544 inhabitants) has reinforced this situation.

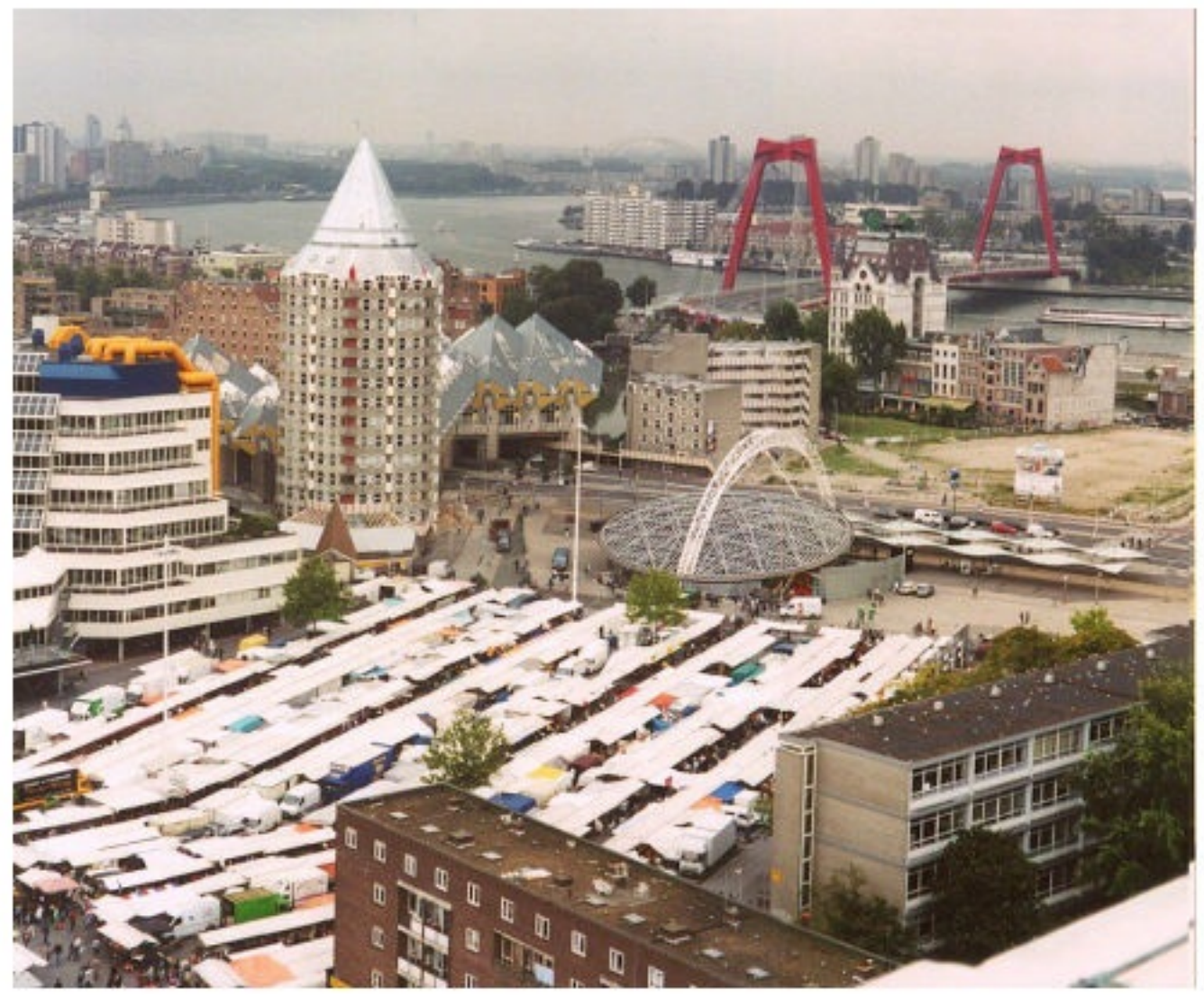

Figure 1. A View of Rotterdam Centre

3.2 There are only a few neighbourhoods, like Hillegersberg, old Kralingen and Prinsenland, where the composition of the housing stock allows for a high level of homogeneity with regard to the socio-economic background of residents. Until the nineteen nineties there has been little building of middle class housing stock. Middle-class dwellings were mainly built in the suburbs of Rotterdam. The existence of post-war housing stock means that (as yet) there are limited possibilities for gentrification in Rotterdam, except for a few small blocks. During the nineteen nineties new dwellings have been built for middle and higher income groups (Van 't Verlaat \& Van der Meer 2002) and, according to the local council, this share should increase from 51 per cent in 2000 to 77 per cent in 2005 (ibid: 21).

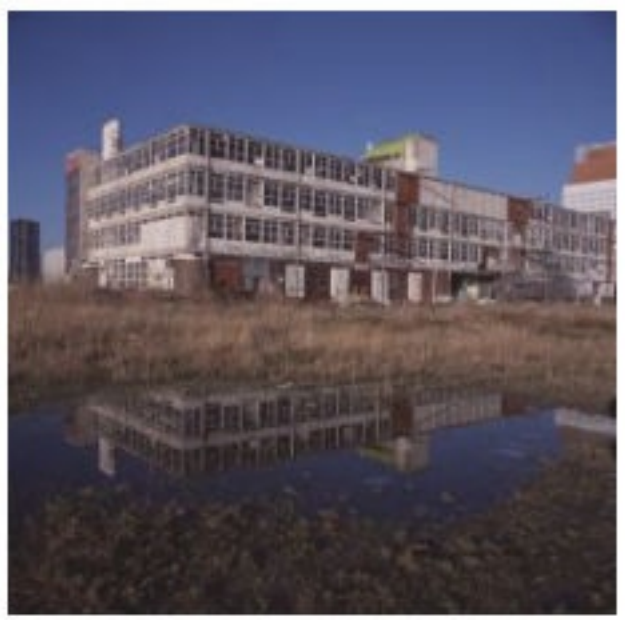

Figure 2. Rotterdam Apartments 


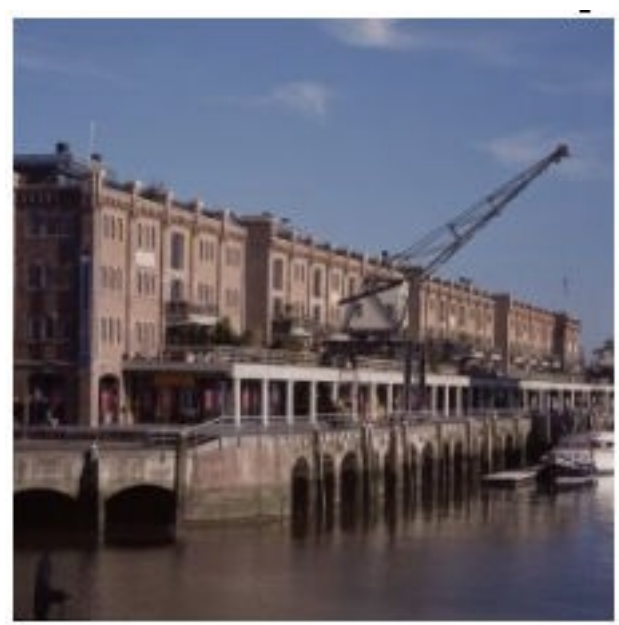

Figure 3. City Centre Loft Apartments

3.3 However, all in all, for many members of the new middle class Rotterdam is not an attractive city to settle in. This has little to do with the type of houses which are on offer, but has a lot to do with the lack of safe and secure residential environments for households in middle and higher income groups. ${ }^{[1]}$ The socalled "Woonstadbeleid" [Urban Living Policy] between 1998 and 2002 aimed at improving the quality of both existing residential areas and new areas for middle and higher income groups. More importantly, the city council at its inauguration in 2002 announced it would tackle issues of safety and dilapidation in the city much more fiercely than had previously been the case.

3.4 Rotterdam had previously had a poor reputation with regard to leisure and entertainment (Vijgen \& Van Engelsdorp Gastelaars 1990). However, much has changed during the past decade. In 2002 the city council issued a brochure called "Happy business in Rotterdam", showing details of the recovery of the cultural economy (Gemeente Rotterdam 2002). The statistics in the brochure show that not only does Rotterdam attract more visitors, they also stay longer and return more often. Visitors are relatively young and many of them live in the greater Rotterdam region. Festivals and big events (like e.g. the Rotterdam Marathon) are increasingly popular. While the centre is still being rebuilt from the Second World War, festivals and events already provide the city with a dynamism that compares favourably to other cities. Annual popular events like the Wereldhavenfestival, Dunya, the Zomercarnaval and the Dance Parade have increasingly made their mark, just as in the past the respectable Museum Boymans van Beuningen or the Kunsthal made their mark.

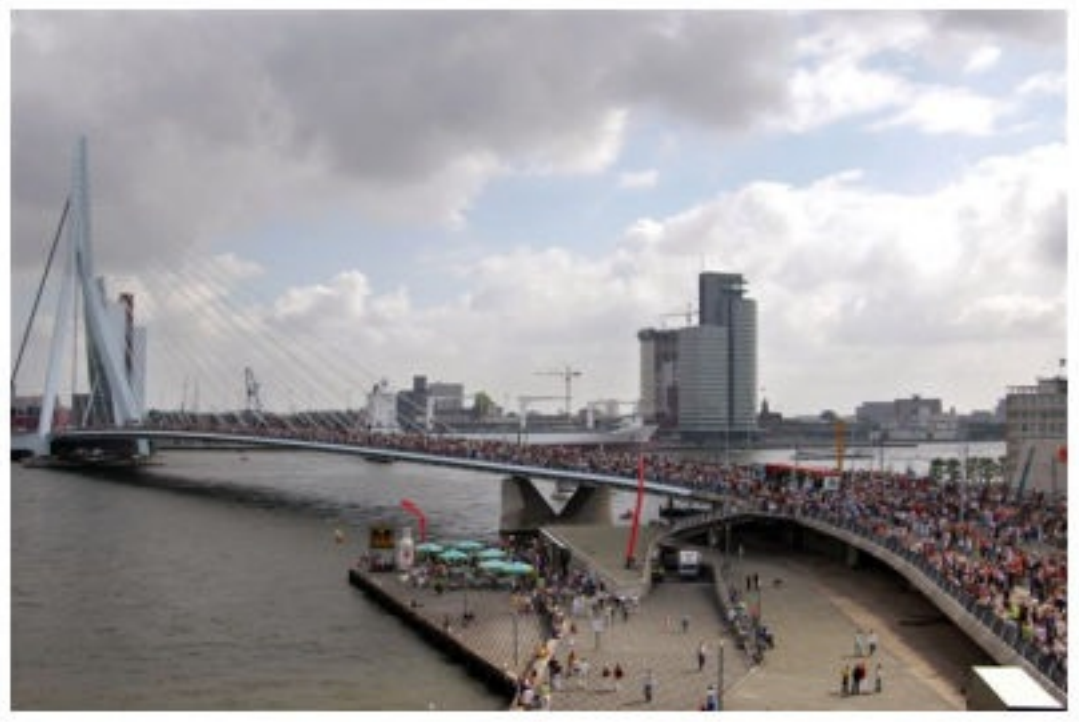

Figure 4. The Dance Parade Rotterdam

3.5 The empirical research on which this paper is based consisted of a survey among 279 highly qualified professionals and managers in selected economic sectors (see below). The survey included questions about the urban ties of new middle class professionals and managers with regard to work, their residential situation and neighbourhood, leisure patterns, social participation, and their psychological urban ties, and was followed by in-depth interviews with a selection of the participants. The occupations of the selected population all are highly knowledge intensive and in the service sector. Three clusters of serviceoccupations were included in the research, which were in some instances overlapping, but which overall 
allow for taking a representative sample of new middle class occupations. They are those in service production occupations, public sector occupations and occupations of a symbolic-analytical nature, mostly in the cultural sector and service-sector. These three clusters of occupations were derived from a theoretical analysis in which macro-historical roots of the new middle class have been traced (Van der Land 2004). It was concluded that there are three tracks along which the new middle class developed into its current form. The first is the technocratic track, which dates back to the industrial revolution and which has produced technical and professional occupations as well as managerial occupations within production processes. Much of the work is aimed at directly facilitating and directing the production of goods and services. The second track concerns the public welfare system. The growth of the welfare state during the post-war years has produced all kinds of new occupations, both in the public as well as the semi-public and private sector. The third track has produced service sector occupations and incorporates two important developments. Firstly, the rise of the cultural economy has involved the development of occupations in which cultural knowledge is produced and distributed. Secondly, the role of knowledge has changed from strongly utilitarian with regard to the production process into knowledge of a more symbolic kind.

3.6 Every participant of the survey was working in or very near to Rotterdam with 45 per cent of them actually living in Rotterdam. The research was carried out in 1996 and 1997. This was a period of economic prosperity, in which the conditions to develop strong attachments may be not so conducive, compared to periods of less prosperity. This is because the degree of freedom to be geographically mobile was high, compared to the years before and after, and if people develop local ties during such a period when they can express their preferences to a high degree, these ties are probably often developed against a background of relatively free choice.

\section{The popularity of Rotterdam's leisure amenities compared to other cities}

First, I explore how the use of leisure amenities in Rotterdam relates to the high amount of geographical mobility this part of the new middle class is supposed to show (Lash \& Urry 1987). I examine the relative importance of Rotterdam's leisure facilities compared to other places. To what extent does the new middle class visit the city of Rotterdam instead of other places? Table 1 shows this popularity as a percentage of all leisure visits to any other place. If this percentage is relatively low, then it suggests that Rotterdam holds a less important position in that respect and that leisure mobility is relatively high. Such a conclusion would fit well into the popular image of the new middle class as a highly mobile group of people. The analysis distinguishes between socio-demographic and socio-economic characteristics and relates these to participation in the leisure city. The analysis has been restricted to people who actually live in Rotterdam. significances: **: $\alpha \leq .01 ;{ }^{*}: \alpha \leq .05$

Age and income have been grouped into three percentiles as best as possible.

Table 1: Percentages of visits to Rotterdam's leisure facilities by members of the new middle class living in Rotterdam as percentages of all leisure visits to any place

restaurants (not going museums fun- outdoor $\mathrm{N}$

for business) out ${ }^{[2]}$ and galleries shopping cafés

sector

$\begin{array}{lllllll}\text { maritime services } & 74 & 77 & 58 & 82 & 74 & (\mathrm{n}=9) \\ \text { local government } & 70 & 89^{*} & 62 & 75 & 70 & (\mathrm{n}=22) \\ \text { university } & 76 & 80 & 53 & 83 & 64 & (\mathrm{n}=12) \\ \text { media } & 79 & 85 & 62 & 83 & 77 & (\mathrm{n}=16) \\ \text { museums/galleries } & 62 & 83 & 51 & 74 & 57 & (\mathrm{n}=12) \\ \text { producer services } & 81^{*} & 82 & 55 & 89^{*} & 80^{*} & (\mathrm{n}=29) \\ \text { banks } & 67 & 70^{* *} & 55 & 81 & 65 & (\mathrm{n}=25) \\ \text { age } & & & & & & \\ 24-31 & 78^{*} & 75^{*} & 49^{*} & 79 & 77^{*} & (\mathrm{n}=44) \\ 32-38 & 67^{*} & 80 & 56 & 82 & 66 & (\mathrm{n}=34) \\ 39-57 & 72 & 87^{* *} & 65^{*} & 84 & 68 & (\mathrm{n}=47) \\ \text { gender } & & & & & & \\ \text { female } & 72 & 81 & 51 & 77 & 71 & (\mathrm{n}=37) \\ \text { male } & 74 & 81 & 59 & 84 & 71 & (\mathrm{n}=88)\end{array}$


income

\begin{tabular}{|c|c|c|c|c|c|c|}
\hline $1.500-3.000$ & 77 & 83 & 53 & 81 & 76 & $(n=49)$ \\
\hline $3.500-4.000$ & 72 & 78 & 61 & 80 & 69 & $(n=39)$ \\
\hline $4.500-11.000$ & 69 & 83 & 57 & 83 & 65 & $(n=34)$ \\
\hline \multicolumn{7}{|l|}{ household } \\
\hline single & 75 & 76 & 49 & 78 & 72 & $(n=38)$ \\
\hline $\begin{array}{l}\text { double, single } \\
\text { earner }\end{array}$ & 66 & 73 & 63 & 85 & 70 & $(n=16)$ \\
\hline double earner & 73 & $85^{\star *}$ & 59 & 83 & 70 & $(n=71)$ \\
\hline children & 71 & $88^{* *}$ & 62 & 83 & 66 & $(n=48)$ \\
\hline no children & 74 & $77^{* *}$ & 54 & 81 & 74 & $(n=77)$ \\
\hline total & 73 & 81 & 56 & 82 & 70 & $(n=125)$ \\
\hline
\end{tabular}

3.7 Table 1 shows that except for visits to museums and galleries, the percentages of visits to Rotterdam compared to other places fluctuate around 70 to 80 per cent. Several conclusions can be drawn from the table. First, it can be concluded that especially for the somewhat older part of the new middle class, Rotterdam's leisure amenities are relatively popular compared to those in other places, whereas the somewhat younger population goes elsewhere more often, but only to visit museums. Second, double income earners are oriented towards Rotterdam more strongly than other households. The need for a time efficient lifestyle might explain this. Close to their dwelling are all kinds of amenities that make the organization of their daily and leisure activities easier. Third, households with children are less mobile with regard to their leisure patterns. Fourth, service producers and public service workers are strongly oriented towards Rotterdam and are less mobile in this respect.

3.8 From this it can be argued that, despite the fact that in popular media as well as in sociology and cultural studies (cf. Featherstone 1990) the image of a highly mobile new middle class prevails, this analysis shows that a large part of Rotterdam's new middle class is in fact not so mobile for leisure. Singles and producers of services are strongly oriented towards the nearby city (cf. Van der Land 1998). Age, household and occupational sector seem to be important factors to explain differences in urban symbolic consumption within the new middle class.

3.9 A comparison between shopping patterns of the new middle class and the entire Rotterdam adult population reveals that the new middle class exclusively shops in Rotterdam even more often than the entire population of Rotterdam on average (in 35 of the 100 cases, whereas the mean for the population is 28 per cent, COS 1996:35.)

3.10 Moreover, a comparison of the popularity of Rotterdam's leisure amenities between the suburbanized new middle class and the entire survey-population shows that differences in visits to Rotterdam are not as great as might be expected (see Table 2) (cf. Burgers \& Van der Land 1997). The fact that a large part of Rotterdam's new middle class does not live in the city does not seem to inhibit active and frequent use of leisure amenities.

Table 2: . Percentages of visits to Rotterdam's leisure facilities by members of the suburban new middle class, as a percentage of all visits to any place

\begin{tabular}{|c|c|c|c|c|c|c|}
\hline & $\begin{array}{l}\text { restaurants (not } \\
\text { for business) }\end{array}$ & $\begin{array}{l}\text { going } \\
\text { out }\end{array}$ & $\begin{array}{l}\text { museums } \\
\text { and galleries }\end{array}$ & $\begin{array}{l}\text { fun- } \\
\text { shopping }\end{array}$ & $\begin{array}{l}\text { outdoor } \\
\text { cafés }\end{array}$ & $\mathrm{N}$ \\
\hline $\begin{array}{l}\text { living in the } \\
\text { suburbs of } \\
\text { Rotterdam }\end{array}$ & 45 & 63 & 52 & 74 & 46 & $(n=36)$ \\
\hline all (total) & 46 & 54 & 44 & 58 & 50 & $(n=279)$ \\
\hline
\end{tabular}

\section{The centre of Rotterdam as a place to live}

3.11 The other, partly overlapping, section of the new middle class who are very important for the functioning of the city centre are those actually living there. As stated earlier, during the 1990s Rotterdam put great 
effort into improving the appeal of the centre to this much sought-after category of residents, both in the residential and leisure domains. Another way of increasing the appeal of Rotterdam to new well-to-do inhabitants has been the cultural revitalization that has been taking place since the early 1990s. Both the policy-programmes "Attractieve Stad" [Attractive City] and "Rotterdam Culturele Hoofdstad 2001" [Rotterdam Cultural Capital 2001] have been means to trying to lure the new middle class to the city. This research has looked into the characteristics of residents who did choose to live in Rotterdam and their motivations. In total 12 per cent of the sample lived in the centre. Some of their characteristics are summarized in Tables 3 and 4.

significance: **: $\alpha \leq .01 ;{ }^{*}: \alpha \leq .05$

Table 3: Some characteristics of the new middle class living in the centre of Rotterdam, in percentages

\begin{tabular}{|c|c|c|}
\hline & $\begin{array}{l}\text { lives in the centre of Rotterdam } \\
(n=34)\end{array}$ & $\begin{array}{l}\text { lives } \\
\text { elsewhere } \\
(n=245)\end{array}$ \\
\hline mean age & $37 y$ & $39 y$ \\
\hline \multicolumn{3}{|l|}{ gender } \\
\hline female & 17 & 21 \\
\hline male & 83 & 79 \\
\hline total & 100 & 100 \\
\hline \multicolumn{3}{|l|}{ household } \\
\hline single & $44^{* *}$ & $22^{* *}$ \\
\hline double, single earner & 6 & 18 \\
\hline double earner & 50 & 60 \\
\hline total & 100 & 100 \\
\hline children living in household & $21^{* *}$ & $51^{* *}$ \\
\hline \multicolumn{3}{|l|}{ sector } \\
\hline maritime & 9 & 16 \\
\hline city council & 15 & 22 \\
\hline university & 12 & 9 \\
\hline museums/galleries & 12 & 6 \\
\hline media & 9 & 18 \\
\hline producer services & $32^{* *}$ & $14^{* *}$ \\
\hline bank & 12 & 16 \\
\hline total & 100 & 100 \\
\hline $\begin{array}{l}\text { mean net income per month (in } \\
\text { fl) }\end{array}$ & $3.773^{*}$ & $4.409^{*}$ \\
\hline
\end{tabular}

significance: *: $\alpha \leq .05$

Table 4: Residential characteristics of the new middle class living in the centre of Rotterdam

lives in the centre of Rotterdam $(n=34)$

time of residence current address

home ownership

76 months lives

elsewhere $(n=245)$

74 months 
3.12 The centrally living urban new middle class appears to a large extent to consist of singles in their thirties, without children, who are potentially mobile as a result of their lack of home ownership. Many of them work in the service production sector. Not only do they work in a highly locally based economic sector (Storper 1997, cf. Van der Land 2004) they are frequent visitors to the city and their urbanity also shows in their choice of residence. Also there is an age-effect (the mean age of the survey participants from the producer service sector was 34 , compared to 40 for the rest of the population). However, when we only select 24-35 year olds from the whole of the sample, then the producer service sector, together with the academic sector, still stands out (see Table 5). Sectoral and occupational factors are both involved, it seems. Furthermore, among the 24-30 year old inhabitants of the city centre, six out of seven are from the producer service sector.

Table 5: Place of residence per economic sector of young members of the new middle class (24-35 years old), in percentages

\begin{tabular}{llll}
\hline & $\begin{array}{l}\text { lives in the centre of Rotterdam } \\
(\mathrm{n}=18)\end{array}$ & lives elsewhere & total \\
& & $(\mathrm{n}=99)$ & $(\mathrm{n}=117)$ \\
maritime services & 11 & 89 & 100 \\
local government & 8 & 92 & 100 \\
university & 27 & 73 & 100 \\
museums/galleries & 4 & 96 & 100 \\
media & 13 & 87 & 100 \\
producer services & 26 & 74 & 100 \\
bank & 14 & 86 & 100 \\
\hline
\end{tabular}

Next it is important to determine the motivation behind people chosing the city centre as a place to live. Answers centre around two key motivations. First, the presence of others plays an important role, both in a negative sense (noise, litter) and a positive sense (diversity, liveliness). Many of the people in this category claim they like the dynamic and surprising atmosphere in cities (cf. O'Connor \& Wynne 1995, Zukin 1995): positive aspects of social density in the city centre dominate. Second, people point to the higher quality of life which can be obtained through the proximity of the available, though expensive, amenities (like nightshops, traiteurs, bagelshops, bars, etc). Also, the vicinity of the work-place is important in this respect (all of them work in Rotterdam). Both the use of amenities and the journey to work should not take too much time. The potential quality of life, seems to be affirmed by the behaviour of the centre inhabitants, i.e. as far as visits to leisure amenities are concerned. From Table 6 it can be argued that those who live in the centre of the city make more use of these amenities than the rest of the new middle class, although only for visits to restaurants the difference is statistically significant. significance: ${ }^{*}: \alpha \leq .05 ;{ }^{* *}: \alpha \leq .01$

Table 6: Visits to Rotterdam leisure facilities by members of the new middle class living in Rotterdam; in absolute numbers per year

\begin{tabular}{lllllll}
$\begin{array}{l}\text { restaurant (not } \\
\text { for business) }\end{array}$ & \multicolumn{2}{l}{ going museums and $\begin{array}{l}\text { fun- } \\
\text { out }\end{array}$} & galleries & \multicolumn{3}{l}{$\begin{array}{l}\text { outdoor } N \\
\text { shopping café }\end{array}$} \\
$41^{* *}$ & 35 & 10 & 17 & 17 & $(n=34)$ \\
$24^{* *}$ & 26 & 8 & 17 & 20 & $(n=91)$ \\
28 & 28 & 8 & 17 & 18 & $(n=125)$
\end{tabular}

lives in the centre $41^{* *}$

lives elsewhere in $24^{\star *}$

Rotterdam

total

28

(1)

3.13 Residential motivations appear predominantly very pragmatic. The results of the survey affirm stereotypes in the Netherlands of 'Rotterdammers' being straightforward and commonsensical. The new middle class has chosen a central location for practical reasons mainly. A strategic residential location enhances the quality of life. Everything that is needed - work, art and culture, entertainment, public transport - all is to hand.

3.14 On these grounds, the Rotterdam urban policy to create more up-market dwellings in the centre seems to be well founded. The development of the city into a leisure city does not (yet) seem to be at odds 
with the residential function. Moreover, the popularity of leisure in Rotterdam to both local inhabitants and visitors highlights the importance of the city - compared to new emerging centres in the urban network. It does not appear that the city centre will whither in the near future.

\section{Symbolic consumption and mental attachments to the city and the city-centre}

4.1 There is a hint of romanticism behind some of the claims about negative effects of consumer culture on the urban ties people develop. It supposes that developing urban attachments would be more common in a time when cities were not as much the consumption domains as they are today. Young new middle class households in Rotterdam, who are at the beginning of their housing career, especially point to the city as their favourite place to live, but they do so often for practical reasons. Can the simple fact that they have chosen the city for these reasons also be interpreted as an indication for 'urban attachment'? And what else makes them feel they belong? Do they feel attached to the centre? Do they feel they are 'Rotterdammers'? Are they proud of the city? Is it their city? An analysis of these issues will be be presented with regard to inhabitants as well as to visitors of the urban centre. I start with the centre-inhabitants.

Table 7: Attachment of centre-inhabitants, in percentages

\section{a. neighbourhood}

lives in the centre of Rotterdam lives $(n=34)$

38 elsewhere $(n=245)$

feels (very) attached to the neighbourhood

feels (very) satisfied with the neighbourhood

76

86

significance: *: $\alpha \leq .05 ;{ }^{* *}: \alpha \leq .01$

Table 7: b. city

\begin{tabular}{lll}
\hline & $\begin{array}{l}\text { lives in the centre of Rotterdam } \\
(\mathrm{n}=34)\end{array}$ & $\begin{array}{l}\text { lives } \\
\text { elsewhere } \\
(\mathrm{n}=245)\end{array}$ \\
$\begin{array}{lll}\text { feels (very) attached to Rotterdam } \\
\text { feels to be a 'Rotterdammer' }\end{array}$ & $\begin{array}{l}88^{* *} \\
73^{* *}\end{array}$ & $63^{* *}$ \\
feels proud of Rotterdam & 91 & $44^{* *}$ \\
appreciation of cultural climate & 7,2 & 76 \\
(grade 1-10) & & 7,4 \\
appreciation of living climate & $7,0^{*}$ & \\
appreciation of public space & 6,1 & $6,6^{*}$ \\
appreciation of restaurants & 7,6 & 6,1 \\
appreciation of leisure climate & 7,1 & 7,3 \\
appreciation of shopping climate & 6,5 & 6,7 \\
appreciation of residential climate & $7,1^{* *}$ & 6,7 \\
\hline
\end{tabular}

4.2 Looking at Table 7, it appears that the centre-inhabitants feel strongly attached to the city in general, more so than the rest of the new middle class living in Rotterdam. Although they feel less attached to their neighbourhood (i.e. in their case a part of the centre) they do identify with other 'Rotterdammers' strongly and many of them feel proud of the city. The residential aspects of Rotterdam are appreciated less, whereas the living climate in general is valued relatively highly. It seems as though they perceive Rotterdam less as a place to live and more as a 'complete environment' ("life here is good, but living here is less good").

4.3 Often, conflicting interests of centre-inhabitants and visitors of the leisure city are stated and they show 
that these two categories experience the city in different ways. Residents e.g. would think highly of a safe residential environment, whereas visitors are more keen to see spectacle and entertainment (Glasson, Godfrey \& Goodey 1995). The first category experiences the city as a daily returning habitat, the second looks for extraordinary special experiences. However, the centre-inhabitants, and especially the highly qualified young and single among them, partly seem to be like tourists in their own city (cf. Urry 1990, Metz 2002). Their pride of the city in general confirms this. When finding out why they feel proud, they refer to the metropolitan characteristics of Rotterdam: especially its international harbour and the all modern architecture that is present. Profiles of residents and visitors partly seem to merge, not only literally (the new middle class resident and visitor are both in their thirties, single and without children), but also symbolically, in the sense that symbols representative of Rotterdam have important meanings for both of them.

4.4 The connection between identification with the city and attachments through symbolic consumption appears, paradoxically, to be more prominent among the new middle class from outside Rotterdam. Members of the suburbanized new middle class who claim to feel 'Rotterdammer' appear to go out more than twice as much in Rotterdam than those who do not (59 times against 24 times per year). The difference is partly made by 'born Rotterdammers', as they go out three times as much as those who are not born in Rotterdam. Their (leisure) ties with the city involve a high level of urban attachment, and this is based on the huge difference in levels of leisure visits to the city between those who say they feel attached to Rotterdam and those who do not. The latter visit the city 16 times a year, the first do so 45 times on average. Hence it does not even seem necessary to live in Rotterdam to feel attached to the city. Symbolic consumption functions as a means though which developing attachments can also occur.

4.5 Next, I analyze the urban attachment of frequent leisure consumers (see Table 8).

significance: *: $\alpha \leq .05 ;{ }^{* *}: \alpha \leq .01$

Table 8: Urban attachments of frequent leisure visitors, in percentages and as a value between 1 and 10

\begin{tabular}{|c|c|c|}
\hline & $\begin{array}{l}\text { visits leisure city } \\
\text { frequently }(n=34)\end{array}$ & $\begin{array}{l}\text { visits leisure city not so } \\
\text { frequently }(n=245)\end{array}$ \\
\hline lives in Rotterdam & $76^{* *}$ & $24^{* *}$ \\
\hline $\begin{array}{l}\text { feels (very) attached to } \\
\text { Rotterdam }\end{array}$ & $82^{*}$ & $64^{*}$ \\
\hline feels a 'Rotterdammer' & 61 & 46 \\
\hline feels proud of Rotterdam & 82 & 77 \\
\hline $\begin{array}{l}\text { appreciation of cultural } \\
\text { climate (grade } 1-10 \text { ) }\end{array}$ & 7,4 & 7,4 \\
\hline appreciation of living climate & 6,8 & 6,6 \\
\hline appreciation of public space & 5,7 & 6,1 \\
\hline appreciation of restaurants & 7,5 & 7,3 \\
\hline $\begin{array}{l}\text { appreciation of downtown } \\
\text { climate }\end{array}$ & 6,9 & 6,8 \\
\hline $\begin{array}{l}\text { appreciation of shopping } \\
\text { climate }\end{array}$ & 6,7 & 6,7 \\
\hline $\begin{array}{l}\text { appreciation of residential } \\
\text { climate }\end{array}$ & 6,4 & 6,4 \\
\hline
\end{tabular}

4.6 Among the frequent leisure consumers, feelings of urban attachment appear again to be stronger than among those who visit leisure amenities less often. Although the percentages of people who say they feel attached to Rotterdam, who identify with 'Rotterdammers' and who are proud of the city are lower compared to the centre-inhabitants, the percentages are still relatively high, especially when we take into account that almost a quarter of them live outside Rotterdam. Their appreciation of diverse aspects of Rotterdam is rather average, including their appreciation of leisure aspects like culture, public space, restaurants, shopping, and so forth.

4.7 The survey also explored the motivation of residents and visitors as to why they feel attached to Rotterdam. The centre-residents answered this particular question with a high level of abstraction, often 
stating that their attachment is something that just goes naturally with living somewhere. Most answers deal with urbanity and image: for example, the city thrives with energy, is dynamic, has international appeal and offers the latest in art and culture. Others explain their attachment in more emotional terms: they feel at home or want to identify with the popular image of a city of hard working people. Only a few people give more specific answers, like that their friends live there also, that they are involved through their job or that it is necessary for their work to know the city well, and that this leads to a certain degree of attachment. The frequent visitors of Rotterdam's leisure amenities provide similar answers. However, no one explicitly refers to urban leisure as a means of attachment. A possible correlation between attachment and symbolic consumption is not that straightforward it seems.

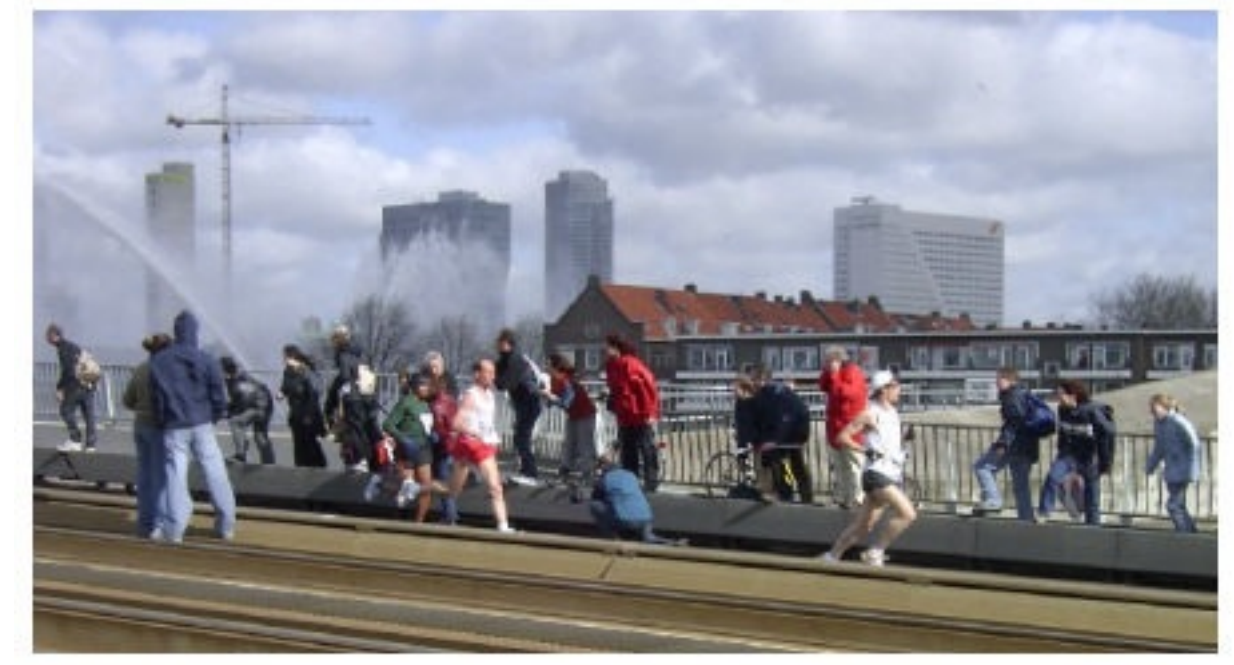

Figure 5. Rotterdam Marathon

\section{Discussion and conclusion}

5.1 What kind of involvement is the attachment visitors and residents point to? Attachment is usually associated with some deeper consciousness of what is 'good' about the city, mostly in terms of urban civic culture (cf. Putnam 1993). Often consumer culture is associated with cursoriness, hedonism and egoism. Consumption is considered something private: there is no collective gain (Slater 1997). Recently, however, more optimistic voices can be heard. Attachments in the domain of 'play' might also be a more playful, 'lighter' kind of attachment, which develops under conditions of play (Allon 1978), like choice, desire, spontaneity and fantasy. Leisure often is a very social activity, which might invoke a feeling of togetherness, possibly enhancing feelings of attachment to the context in which this takes place (Goffmann 1961, Maffesoli 1996). People can get in contact with local cultural identity, the local sense of place (Eyles 1985, Shields 1992). 


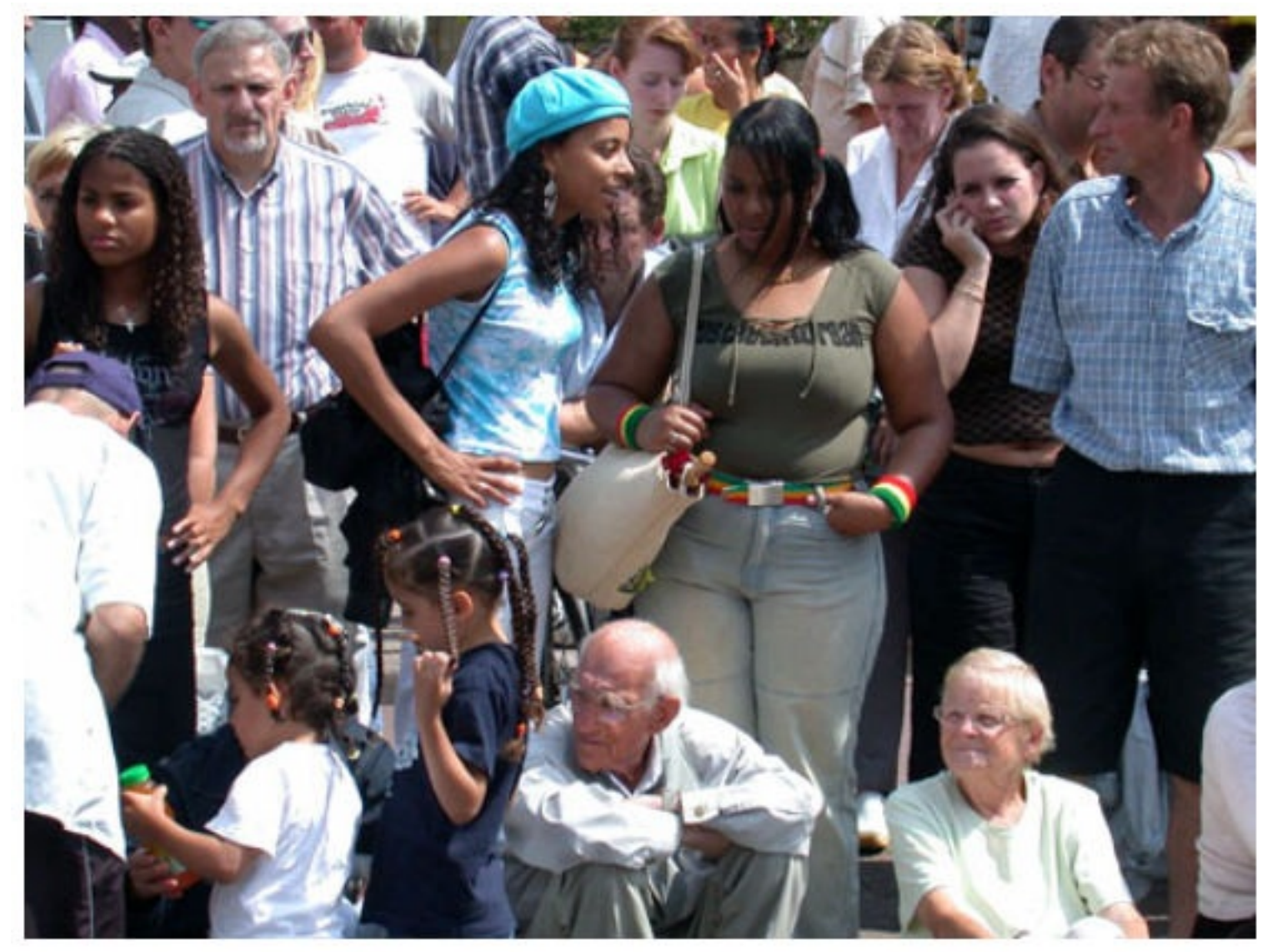

Figure 6. Rotterdam Summer Carnival

5.2 The survey indicates that the attachments of the new middle class are often of a rather abstract nature. City centre-inhabitants appear to have an encompassing, but rather crude kind of attachment to their residential environment. They feel attached to the city as a whole and less with the centre, where they live. Attachments of visitors also point to the city as a 'complete' experience. What they feel attached to is not specific, to say the least, and is to a certain extent superficial and of a cursory nature. When they move to another city or when they visit the city less, their attachment might disappear quickly. 


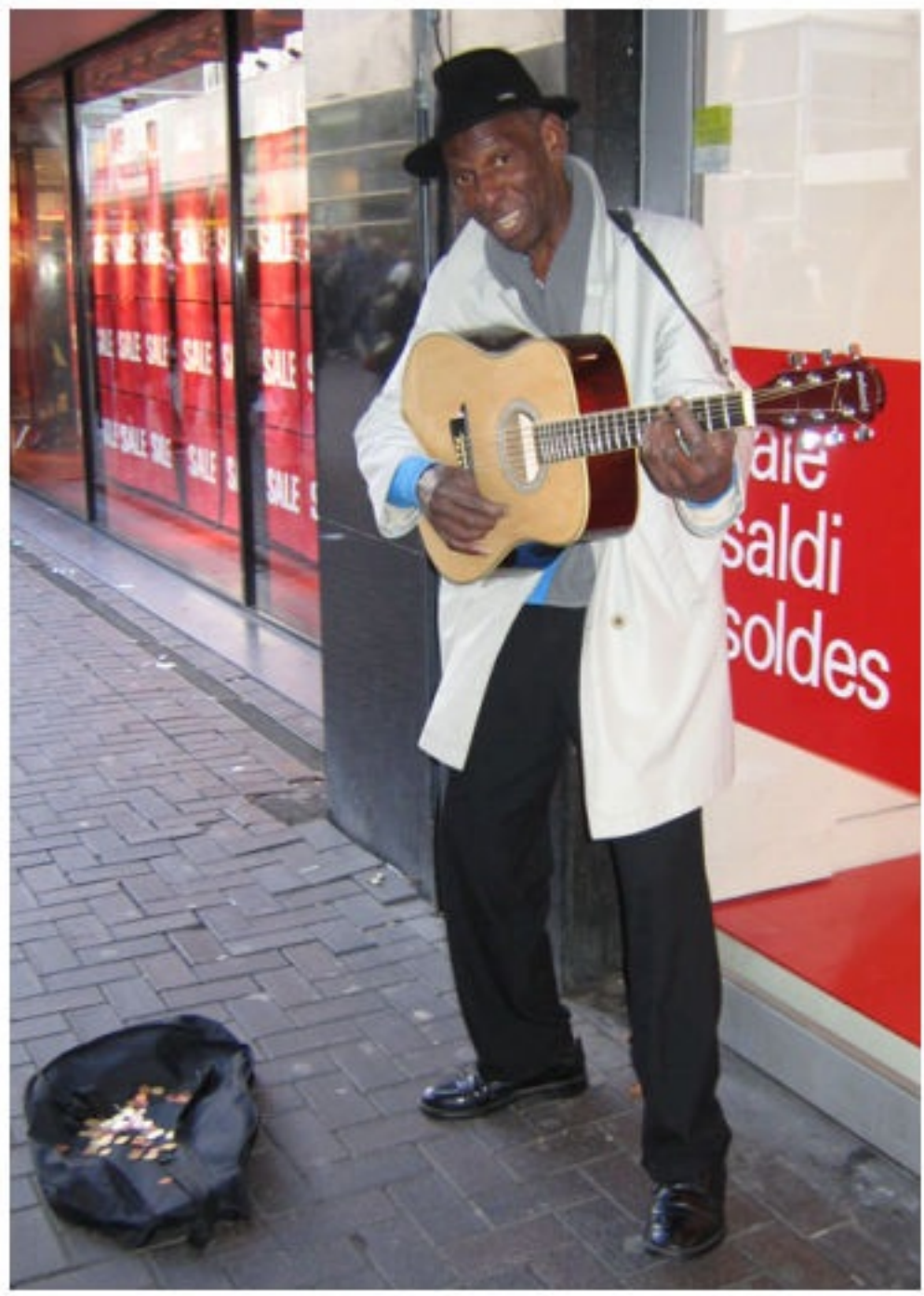

Figure 7. Musician in Rotterdam Centre

5.3 Despite the somewhat pessimistic stance that is often taken in the debate on the city as a consumption domain, regarding social and cultural effects, the survey does, however, provides some clues for a possibly more optimistic view. This idea itself is not new, but consumption has not often been explicitly related to the issue of developing ties and feelings of attachment.

5.4 Consumption plays an increasingly important role in identity construction, in the identification with others and in the identity construction of the self. Consumption is an effective means of distinguishing an individual's personality intentionally and actively from others. Therefore, the context in which symbolic consumption takes place (the city and especially the city centre) in a social, cultural and physical sense is important. Two factors can be identified in this context, which in their interdependence facilitate the development of attachment, namely frequency and intensity. Frequency refers to recurring symbolic consumption. Places, people, noises, products and particular images and landmarks (a bridge, a square, the decorum of a street parade) emerge and stick because of the returning visits. Intensity refers, rather paradoxically, to the intense experiences that can be found in the city. As frequency and intensity increase, the chances that one can identify with the context in which symbolic consumption takes place also increase. Although the city is not literally their city by birth or by residence, people still can identify with it to a great extent. The city is 'acquired' so to speak and made into a city 'for one's own'. 


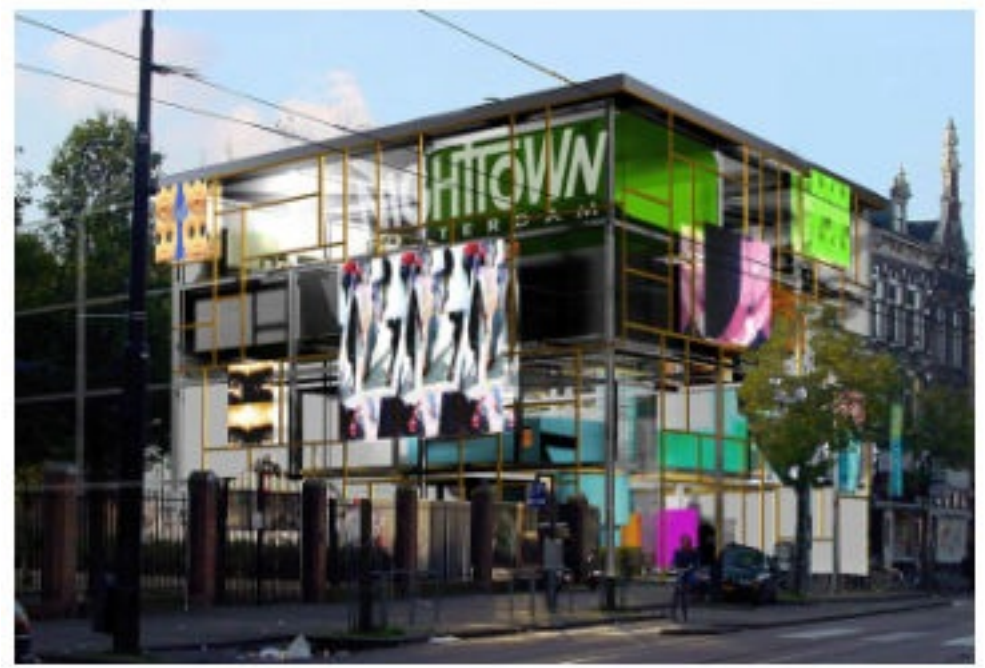

Figure 8. Nighttown: Venue for Popular Music

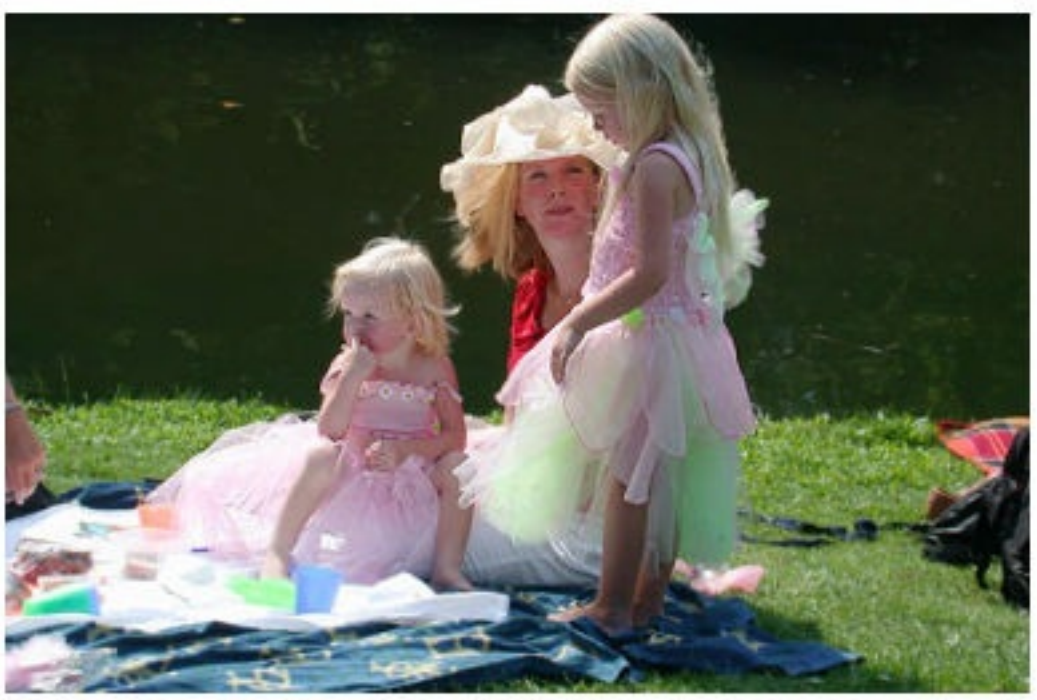

Figure 9. Rotterdam Romantic Music Day

5.5 This indicates that the presence of leisure facilities in cities, beside their functional value, also has a psychological (cognitive and emotional) dimension, which is closely connected to the presence of other social beings. Big events, like football matches, parades or e.g. the opening of a bridge, or places where many people gather (like in shopping malls, concert halls or festivals) have a certain social quality that goes beyond the mere presence of just a lot of people. Maffesoli and in his footsteps Shields call this quality, after Simmel, 'sociality' (Shields 1992). Sociality has become an important part of consumption, because it seems to offer people ideas on how to change or form identity. It emerges where people gather with a common goal, share the same phenomena and similar feelings, and create a sense of togetherness. It invokes a sense of belonging and communion (Shields, in Maffesoli 1996). In this respect the emotional aspects of sociality, like identification with local history, local sayings, feelings of pride with what is achieved in the city, or the presence of symbolic spots can enhance one's attachment with the city and the city centre.

5.6 Members of the new middle-class living in the centre of Rotterdam appear to be psychologically attached to the city, as are the frequent visitors of leisure facilities who do not live in the city at all, but only work there. The symbolic consumption of the city, its cultural products and the sociality the city contains, contribute to the way and the extent to which people identify with the city. Symbolic and emotional aspects of social interactions based on consumption in other words facilitate the development of attachments to the city. The fact that the new middle class living in and around Rotterdam is not very mobile with regard to their leisure patterns, seems to stimulate this identification to develop. As marriages are increasingly based on emotional grounds and decreasingly on rational grounds, but are also increasingly ended for emotional reasons, so might these attachments also turn out to be more fragile than rationally based attachments. Still, urban attachments of the new middle class might in a sense be cursory and partial, they are nevertheless real and seem to be intensified by symbolic consumption, rather than the other way around. 


\section{Notes}

1 Personal conversation with senior civil servant of the Rotterdam Development Corporation

(OntwikkelingsBedrijf Rotterdam).

2 Movie, musical concert, dance performance, club, bar etc.

\section{References}

ALLON, N. (1978) Urban Lifestyles. W.C. Brown, Dubuque.

ALTMAN, I. and S. Low (1992) (eds.) Place Attachment. Plenum Press, London.

BOURDIEU, P. (1992) [1984] Distinction: a Social Critique of the Judgement of Taste. Routledge, London.

BURGERS, J. and M. van der Land (1997) Thuis in de Uitstad. [At home in the leisure city] In A. Reijndorp, V. Kompier and L. de Haas (eds.). Leefstijlen. Wonen in de 21e Eeuw. [Lifestyles. Living in the 21st century] NAi, Rotterdam.

CAMPBELL, C. (1987) The Romantic Ethic and the Spirit of Modern Consumerism . Blackwell, Oxford.

COS (1996) Binding aan Rotterdam. Een Verkennend Onderzoek. [Attachment to Rotterdam. An explorative study]COS, Rotterdam.

EYLES, J. (1985) Senses of Place.Silverbrook Press, Warrington.

FEATHERSTONE, J. M. (1990) The Paradox of Culture and the Globalization of Diversity. ISOR, Utrecht. [Phd thesis].

FLORIDA, R. (2002) The Rise of the Creative Class.Basic Books, New York.

GEMEENTE ROTTERDAM (2002) Plezierige Zaken in Rotterdam. Vrije Tijdseconomie in Cijfers 2001. [Happy business in Rotterdam. Leisure economy in numbers 2001]OntwikkelingsBedrijf Rotterdam, Rotterdam.[brochure]

GLASSON,J., K. Godfrey and B. Goodey (1995) Towards Visitor Impact Management; Visitor Impacts, Carrying Capacity and Management Responses in Europe's Historic Towns and Cities.Aldershot, Avebury.

GOFFMAN, E. (1961) Encounters. Two Studies in the Sociology of Interaction. Bobbs-Merrill, Indianapolis.

GOTTDIENER, M. (1997) The Theming of America: Dreams, Visions, and Commercial Spaces. Harper Collins, New York.

HAJER, M. and A. Reijndorp (2002) Op Zoek naar Nieuw Publiek Domein. Analyse en Strategie. [Looking for new public domain. Analysis and strategy]NAi Uitgevers, Rotterdam.

HANNIGAN, J. (1998) Fantasy City: Pleasure and Profit in the Postmodern Metropolis. Routledge, London.

KNULST, W.P. (1992) Waarom blijt het cultureel rendement van een stijgend opleidingsniveau achter bij de verwachtingen? [Why does the cultural revenue of increasing educational levels not live up to the expectations?] In P. Dekker and M.J. Konings-van der Snoek (eds.). Sociale en Culturele kennis. Hoe Bevalt de Nederlandse Vrouw? en 44 andere Vragen Beantwoord. [Social and cultural knowlegde] Sociaal en Cultureel Planbureau/VUGA, Rijswijk/Den Haag.

LASH, S. and L. Urry (1987) The End of Organized Capitalism.Polity Press, Cambridge.

LEY, D. (1996). The New Middle Class and the Remaking of the Central City.Oxford University Press, New York.

LOFLAND, L.H., (1989) 'Social life in the public realm: a review.' Journal of Contemporary Ethnography 17, 4 (January), 453-482.

MAFFESOLI, M. (1996) The Time of the Tribes. The Decline of Individualism in Mass Society. Sage, London.

METZ, T. (2002) Pret! Leisure en Landschap. [Fun! Leisure and landscape]NAi Uitgevers, Rotterdam. 
MOMMAAS, H. (2002) De Ruimte als 'Event'. Over de Noodzaak van 'Cultureel Structuurbeleid'. [Space as 'event'. On the need for a cultural structure policy] [Lecture]

O'CONNOR, J. and D. Wynne (1995) City Cultures and the 'New Cultural Intermediaries'. Institute for Popular Culture, Manchester.

SASSEN, S. (1991) The Global City: New York, London, Tokyo.Princeton University Press, Princeton, NJ.

SCHMIDT-RELENBERG, N. (1968) Soziologie und Städtebau. Versuch einer Systematischen Grundlegung.Karl Krämer Verlag, Stuttgart/Bern.

SCHULZE, G. (1992) Die Erlebnisgesellschaft. Kultursoziologie der Gegenwart. [The experience society. Cultural sociology of the present] Campus Verlag, Frankfurt/New York.

SCOTT,A.J. (1997) 'The cultural economy of cities.' International Journal of Urban and Regional Research 21 (1997), 2, 323-339.

SHIELDS, R. (ed.) (1992) Lifestyle Shopping: the Subject of Consumption.Routledge, London/New York.

SLATER, D. (1997) Modernity and Consumer Culture. Polity Press, Cambridge.

SMITH, N. (1996) The New Frontier. Gentrification and the Revanchist City. Routledge, New York.

STORPER, M. (1997) The Regional World. Territorial Development in a Global Economy. The Guildford Press, New York etc.

URRY, J. (1990) The Tourist Gaze. Leisure and Travel in Contemporary Societies.Sage, London.

VAN DE WOUDEN, R. and Erica de Bruijne (2001) De stad in de omtrek. Problemen en perspectieven van de vier grootstedelijke gebieden in de Randstad. [The contours of the city. Problems and perspectives of the four metropolitan areas in the Randstad.]Sociaal en Cultureel Planbureau, Rijswijk.

VAN DER LAND, M. (1998) 'Myths of mobility. On the geography of work and leisure among Rotterdam's new middle class'. Netherlands Journal of Housing and the Built Environment, February, 117-135.

VAN DER LAND, M. (2004) Vluchtige Verbondenheid. Stedelijke Bindingen van de Rotterdamse Nieuwe Middenklasse. [Cursory connections. Urban ties of Rotterdam's new middle class.]Amsterdam University Press, Amsterdam.

VAN 'T VERLAAT, J. and J. van der Meer (2002). Quality of life als strategisch beleidsthema. [Quality of life as a strategic policy issue].OBR/dS+V, Rotterdam.

VIJGEN, J. and R. E. van Engelsdorp Gastelaars (1990) 'Hoe stedelijk is de Maasstad? Voorzieningen, bewoners en leefpatronen in Rotterdam en Amsterdam. ' How urban is the Maasstad? Amenities, residents and living patterns in Rotterdam and Amsterdam] K.N.A.G. Geografisch Tijdschrift 24, 3, 241-251.

WENTHOLT, R. (1969) De binnenstadsbeleving en Rotterdam. [Inner city experience and Rotterdam]. Ad. Donker, Rotterdam.

WYNNE, D. (2002) Leisure, Lifestyle, and the New Middle Class. A Case-Study.Routledge, London/New York.

ZUKIN, S. (1991) Landscapes of Power. From Detroit to Disney World. University of California Press, Berkeley.

ZUKIN, S. (1995) The Cultures of Cities. Blackwell, London.

ZUKIN, S. (1998) 'Urban Lifestyles: diversity and standardisation in spaces of consumption.' Urban Studies 35 (1998), 5-6, 825-839. 